Novi Febriyanti, Kiky Dzakiyah

ANALISIS PENGELOLAAN KEUANGAN ISLAM PADA

PELAKU USAHA KECIL BISNIS ONLINE

\title{
ANALISIS PENGELOLAAN KEUANGAN ISLAM PADA \\ PELAKU USAHA KECIL BISNIS ONLINE \\ ANGGOTA HIMPUNAN PENGUSAHA MUDA INDONESIA \\ PERGURUAN TINGGI UNIVERSITAS ISLAM NEGERI SUNAN AMPEL SURABAYA (HIPMI PT UINSA SURABAYA)
}

\author{
Novi Febriyanti \\ UIN Sunan Ampel Surabaya \\ novikfbr@gmail.com \\ Kiky Dzakiyah \\ UIN Sunan Ampel Surabaya \\ kdzakiyah@gmail.com
}

\begin{abstract}
Abstrak
Perkembangan teknologi saat ini memaksa semua pelaku industri untuk mengikutinya agar dapat bertahan dalam persaingan. Teknologi telah membawa banyak kemudahan dalam transaksi jual beli, tidak heran jika bisnis online semakin meningkat. Dibalik kemudahan tersebut, sebagai seorang muslim terdapat pedoman dasar yang harus tetap dijalankan dalam bermuamalah di era globalisasi ini. Artikel ini bermaksud ingin menganalisis bagaimana pengetahuan pengusaha online yang tergabung dalam HIPMI PT UINSA dan bagaimana praktik pengelolaan keuangan Islam pada usaha yang mereka jalankan. Menggunakan metode penelitian kualitatif dengan pendekatan fenomenologi penelitian ini mengobservasi 10 informan pelaku usaha online atau e-commerce lainnya yang tergabung dalam HIPMI PT UINSA. Hasil penelitian ini membuktikan bahwa seluruh informan memiliki pengetahuan mengenai konsep pengelolaan keuangan Islam. Para pengusaha juga telah menerapkan pengelolaan keuangan Islam melalui pengalokasian anggaran untuk zakat, infak dan sedekah. Selain itu para pelaku usaha juga sudah memiliki dana tabungan dan investasi untuk usahanya. Namun mayoritas pengusaha masih menerapkan pengelolaan keuangan secara sederhana. Terkait penganggaran, laporan keuangan, dan manajemen kas belum diterapkan secara terstuktur. Pengetahuan mengenai perencanaan dan laporan keuangan serta kemudahan dengan adanya aplikasi akuntansi digital baiknya dimanfaatkan oleh para pelaku usaha online guna keberlangsungan dan pengembangan usaha di masa yang akan datang.
\end{abstract}

Kata kunci: Bisnis Online, Pengelolaan Keuangan Islam.

\section{PENDAHULUAN}

Munculnya internet telah banyak dimanfaatkan sebagai wadah bagi para pelaku UMKM untuk menjual produknya secara online, dengan kemudian saat ini biasa disebut dengan istilah bisnis online atau online shop. Melihat berbagai kemudahan tersebut tidak heran jika bisnis online semakin meningkat, transaksi jual beli pun menjadi semakin mudah dilakukan. Bisnis online secara sederhana dapat 
diartikan sebagai suatu proses jalanannya transaksi jual beli yang dilakukan secara online dengan menggunakan jaringan media internet. Dalam Islam bisnis online salah satu akad yang bisa digunakan yakni dengan transaksi jual beli menggunakan akad salam. Berdasarkan Fatwa Dewan Syariah Nasional Majelis Ulama Indonesia (DSN MUI) Nomor 05/DSNMUI/IV/2000, jual beli salam diartikan sebagai jual beli barang dengan cara pemesanan dan pembayaran harga lebih dahulu dengan syarat-syarat tertentu. ${ }^{1}$ Perihal jual beli baik online maupun offline Islam menggambarkan tata cara yang baik dan benar agar tidak ada kerugian diantara menusia-manusia yang melakukan transaksi jual beli. Salah satu dasar hukum perihal jual beli terdapat dalam Surah an-Nisa ayat $4: 29^{2}$

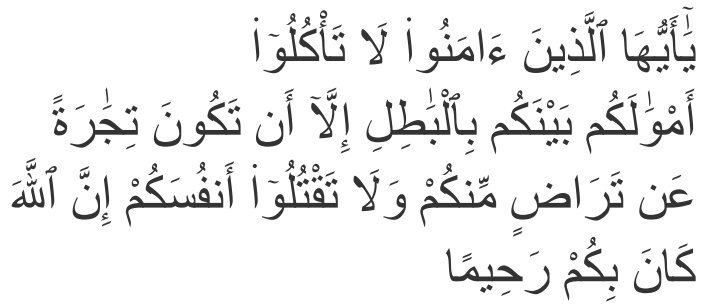

"Hai orang-orang yang beriman, janganlah kamu saling memakan harta sesamamu dengan jalan yang bathil, kecuali dengan jalan perniagaan yang berlaku dengan suka sama-suka di antara kamu",3

\footnotetext{
${ }^{1}$ Arip Purkon, Bisnis Online Syariah, (Jakarta: Gramedia Pustaka Utama, 2014), 35.

${ }^{2}$ Al Qur'an 4: 29

3 Departemen Agama Republik Indonesia, AlQur'an dan Terjemah (Bandung: Diponegoro, 2005), 140.
}

Perkembangan bisnis online atau online shop yang positif ini tentu saja harus diimbangi dengan manajemen yang baik agar usaha tersebut tidak hanya bersifat jangka pendek dan bisa berkembang. Bagi seorang pengusaha muslim, manajemen keuangan untuk suatu usaha diharuskan sesuai dengan tuntunan syariat Islam. Hal tersebut baik bagi harta milik pribadi maupun hasil usahanya. Pengelolaan harta seperti ini harus sesuai dengan syariat Islam, baik hal dalam cara memperolehnya, membelanjakannya, mengembangkannya, dan pendistribusiannya. Konsep manajemen keuangan ini kemudian dikenal dengan sebutan Islamic Financial Planning. ${ }^{4}$

Universitas Islam Negeri Sunan Ampel Surabaya telah menanamkan jiwa kewirausahaan pada mahasiswa/i-nya melalui program mata kuliah, terbukti dengan unit-unit usaha yang dikembangkan di lingkungan kampus, serta munculnya komunitas dan laboratorium bisnis sebagai penunjang pembekalan kegiatan bisnis mahasiswa/i-nya. Salah satu komunitas yang cukup aktif dalam pergerakan bisnis di dalam kampus UINSA adalah Himpunan Pengusaha Muda Indonesia Perguruan Tinggi Universitas Islam Negeri Sunan Ampel Surabaya (HIPMI

\footnotetext{
${ }^{4}$ Agus Purnomo, Atika Zahra Maulida, "Implementasi Islamic Financial Planning dalam Perencanaan Keuangan Pengusaha Muslim Lumni Gontor", Nuansa Vol. 14 N0. 1 (I Januari - Juni 2017), 105.
} 
PT UINSA). HIPMI adalah Himpunan Pengusaha Muda Indonesia yakni organisasi independen non partisan para pengusaha muda Indonesia yang bergerak di bidang perekonomian dari kalangan perguruan tingi dan program peningkatan kemitraan dengan Pemerintah.

Berdasarkan uraian tersebut, penulis ingin memaparkan bagaimana pengelolaan dan perencanaan keuangan bagi pengusaha online shop yang masuk pada anggota HIPMI PT UINSA secara Islami. Penelitian ini penting dilakukan untuk mengetahui pengelolaan keuangan Islam apa saja yang telah diterapkan pada bisnis online. Hasil penelitian ini juga bisa dijadikan sebagai pedoman apabila bisnis online tersebut belum menerapkan pengelolaan keuangan secara Islami sesuai dengan syariat yang bebas dari praktek maysir, gharar, riba dan semua yang diharamkan Allah SWT guna mendapatkan ke-maslahatan bersama.

Dalam artikel ini, penulis akan menggunakan field research (studi lapangan) yaitu penelitian yang dimaksudkan untuk mempelajari secara intensif tentang latar belakang keadaan dan posisi saat ini, serta interaksi lingkungan unit sosial tertentu. ${ }^{5}$ Pada penelitian ini penulis mengambil objek penelitian pada pelaku usaha online shop yang telah bergabung pada komunitas Himpunan Pengusaha Muda Indonesia

\footnotetext{
${ }^{5}$ Sudarwan Danim, Menjadi Peneliti Kualitatif,
} (Bandung: Pustaka Setia, 2002), 55.
Perguruan Tingga Universitas Islam Negeri Sunan Ampel Surabaya (HIPMI PT UINSA). Metode penelitian yang digunakan adalah kualitatif dengan pendekatan fenomenologi untuk menggali pengalaman individu dan menemukan makna dari pengalaman tersebut. Peneliti menarik kesimpulan dari partisipan atau responden tentang kondisi sosial yang terjadi saat $\mathrm{ini}^{6}$ terkait bagaimana pengeloaan keuangan Islam para pelaku usaha online shop atau pelaku usaha yang berbasis e-commerce lainnya.

\section{BISNIS ONLINE}

Bisnis online atau yang disebut juga dengan bisnis e-commerce merupakan proses pembelian, penjualan, atau pertukaran barang, jasa dan informasi melalui jaringan komputer termasuk internet. E-commerce digolongkan menjadi lima, yaitu Business to Consumer (B2C), Business to Business (B2B), Consumer to Consumer (C2C), Peer to Peer (P2P), dan Mobile-Commerce (M-Commerce) ${ }^{7}$ Pada transaksi yang menggunakan $e$ -

\footnotetext{
${ }^{6}$ W. Lawrence Neuman dalam Naili Saadah, Perencanaan Keuangan Islam Sederhana dalam Bisnis E-Commerce pada Pengguna Online Shop, Economica: Jurnal Ekonomi Islam, Volume 9, Nomor 1 (2018), 114

7 Shabur Miftah et al, "Implementasi ECommerce Sebagai Media Penjualan Online (Studi Kasus Pada Toko Pstbrik Kota Malang), Jurnal Administrasi Bisnis Vol 29 No 1 (Desember 2015), 3.
} 
commerce terdapat 3 metode pembayaran yang dapat digunakan:

1. Online Procesing Credit Cart

Metode ini digunakan untuk produk yang bersifat retail dimana mencakup pasar yang sangat luas yaitu seluruh dunia. Pembayaran dilakukan secara langsung atau saat itu juga

2. Money Transfer

Pembayaran dalam metode ini lebih aman namun membutuhkan biaya fee bagi pihak penyedia jasa money transfer untuk mengirim sejumlah uang ke Negara lain.

3. Cash on Delivery

Pembayaran dengan bayar di tempat ini hanya bisa dilakukan jika konsumen langsung data ke toko tempat produsen menjual produknya atau berada dalam satu wilayah yang sama dengan penyedia jasa.

Saat ini e-commerce menjadi suatu kebutuhan primer bagi pelaku industri untuk memenangkan persaingan. Hal ini terjadi tak lain karena berbagai kemudahan dan keefektifan yang ditawarkan oleh $e$ commerce. E-commerce telah merevolusi perilaku penjual dan konsumen dalam bertransaksi, dimulai dari menawarkan barang, memasarkan hingga bertransaksi. Semua dilakukan tanpa batas waktu dan jarak dan dilakukan tanpa perlu bertatap muka secara langsung.

Banyak pelaku usaha, termasuk usaha mikro dan kecil memanfaatkan internet sebagai upaya meningkatkan bisnisnya dan tuntutan untuk selalu mengikuti perkembangan dunia global yang mengharuskan untuk selalu bertindak kreatif. Diharapkan dengan pemanfaatan internet ini memberikan dampak pada akselerasi perkembangan dunia usaha mikro dan kecil ini. Upaya para pelaku usaha kecil dalam memanfaatkan e-commerce untuk menjual produk dan jasanya ini sering juga disebut dengan online shop.

\section{PENGELOLAAN KEUANGAN ISLAM}

Dalam Islam praktek manajemen keuangan harus sesuai dengan syariat Islam, baik dalam cara memperolehnya, membelanjakannya, mengembangkannya dan pendistribusiannya. ${ }^{8}$ Manajemen harta atau kekayaan yang dapat dilakukan oleh manusia terbagi dalam dua kategori: (1) mencari atau mendapatkan kekayaan (kasb) yang dikenal dengan istilah ekonomi yaitu pendapatan dan (2) menggunakan atau membelanjakan kekayaan yang diperoleh (infaq) atau yang dikenal dengan istilah ekonomi sebagai pengeluaran. Konsep ini kemudian dikenal dengan istilah Islamic Financial Planning. Islamic Financial Planning mengakomodir kebutuhan para pengusaha-pengusaha muslim yang

\footnotetext{
8 Amir Syarifuddin, Garis-Garis Besar Fiqh, (Jakarta:Prenada Media,2003), 181.
} 
notabene sering bersentuhan dengan dunia financial.

Pengelolaan keuangan yang baik adalah pengelolaan dalam mendapatkan dana dan menggunakan dana tersebut dengan efisien, sehingga perusahaan mendapatkan laba dan dapat bertahan di masa mendatang. ${ }^{9}$ Secara sederhana konsep pengelolaan keuangan yang perlu diperhatikan oleh pelaku usaha antara lain:

1. Memisahkan antara keuangan usaha dengan keuangan pribadi. Saat menjalankan sebuah bisnis, sebaiknya memisahkan rekening pribadi dan bisnis. Hal ini untuk menghindari pemakaian uang hasil bisnis untuk keperluan pribadi. ${ }^{10}$

2. Melakukan pencatatan terhadap seluruh transaksi yang terjadi. Pencatatan dilakukan ketika tedapat uang masuk dan keluar. Hal ini bertujuan untuk mengetahui jumlah uang yang diperoleh dari transaksi yang terjadi dan peruntukan pengeluaran untuk keperluan usaha. $^{11}$

\footnotetext{
${ }^{9}$ Intan Saferi, Sri Retno Handayani, "Identifikasi Pengelolaan Keuangan terhadap Peluang Usaha Online", Journal and Proceeding Fakultas Ekonomi dan Bisnis Unsoed Vol. 4 No. 1 (2014), 848.

10 Federal Deposit Insurance Corporation, "Fueling Your Business: A Guide to Financing Your Small Business", dalam www.fdic.gov diakses pada 20 Maret 2019.

${ }^{11}$ Yuni Karniawati, "Pemahaman dan penerapan Pencatatan Keuangan Pada Usaha Mikro dan Kecil (UMK) dalam Usaha Furniture Mebel", (Skripsi-Universitas Airlangga, 2018), 26
}

3. Melakukan pencatatan pembelian. Pencatatan pembelian meliputi seluruh transaksi pembelian barangbarang yang akan dijual, berfungsi pula untuk mengetahui harga perolehan dari suatu barang. Hal ini penting agar dapat menentukan harga jual sehingga tidak menimbulkan kerugian karena harga jual yang terlalu rendah dari perolehan barang.

4. Melakukan pencatatan persediaan barang. Catatan ini berisi tentang barang-barang yang tersedia ditambah barang masuk, dikurangi barang yang keluar. Catatan ini berfungsi untuk mengetahui berapa jumlah persediaan yang dimiliki usaha.

5. Mencatat biaya operasional. Biaya ini meliputi biaya lain-lain seperti biaya pulsa, biaya listrik, biaya air, dan lain-lain.

6. Menentukan dan mencatat biaya gaji karyawan, termasuk pemilik sendiri atau siapapun yang digunakan tenaganya oleh perusahaan.

7. Melakukan pemeriksaan keuangan secara berkala dan teratur dan membuat laporan keuangan yang baik.

\section{HIPMI PT UINSA}

Dalam penelitian ini, penulis mewawancarai beberapa informan yang terhimpun dalam Himpunan Pengusaha 
Muda Indonesia Perguruan Tinggi Universitas Islam Negeri Sunan Ampel Surabaya (HIPMI PT UINSA) sebagai berikut:

\begin{tabular}{|l|l|l|}
\hline No & \multicolumn{1}{|c|}{$\begin{array}{c}\text { Nama } \\
\text { Pengusaha }\end{array}$} & \multicolumn{1}{|c|}{ Nama Usaha } \\
\hline 1 & $\begin{array}{l}\text { Fita Elentri } \\
\text { Chyntia Putri }\end{array}$ & Antaradin Hijabs \\
\hline 2 & Rafly Akmal & $\begin{array}{l}\text { Gang Buntu } \\
\text { Secondhand } \\
\text { Brand }\end{array}$ \\
\hline 3 & Nayla Fransiska & $\begin{array}{l}\text { Gang Buntu } \\
\text { Women Stuff }\end{array}$ \\
\hline 4 & $\begin{array}{l}\text { Angga Dwi } \\
\text { Kurniawan } \\
\text { Kusuma }\end{array}$ & Es Buto Ijo \\
\hline 5 & Muhammad Afif & $\begin{array}{l}\text { Jasa Pemasaran } \\
\text { Properti }\end{array}$ \\
\hline 6 & Aqidatul Izza & Agen Kaos Kaki \\
\hline 7 & Hilya & Thanaya.id \\
\hline 8 & Detri Wijayanto & Katering Mak Ra \\
\hline 9 & Fahmi Fauzil & $\begin{array}{l}\text { Indah Kargo } \\
\text { Semolowaru }\end{array}$ \\
\hline 10 & $\begin{array}{l}\text { Amani } \\
\text { Khairunnisa }\end{array}$ & $\begin{array}{l}\text { Pempek Matahari } \\
32\end{array}$ \\
\hline
\end{tabular}

Terkait pemahaman pelaku usaha kecil bisnis online anggota HIPMI PT UINSA mengenai konsep pengelolaan keuangan Islam peneliti menyimpulkan bahwa sebagian besar pelaku usaha online telah memahami konsepnya. Definisi pengelolaan keuangan pada dasarnya merupakan cara bagaimana seseorang mengelola atau mengatur siklus keuangan sehingga biaya yang dikeluarkan tidak melebihi pendapatan yang diterima. ${ }^{12}$ Pengelolaan keuangan secara Islami lebih mengutamakan untuk menghindari adanya penghasilan yang tidak halal, seperti adanya riba, maysir, gharar dan juga mengutamakan untuk menyisihkan sebagian rezekinya untuk dibelanjakan di jalan Allah seperti mengeluarkan zakat, infaq, dan sedekah. 13

Sesuai dengan teori bahwa dalam pengelolaan keuangan dalam Islam harus mengeluarkan zakat, infaq dan sedekah. ${ }^{14}$ Dari 10 informan 8 pelaku usaha online dalam penelitian ini telah menerapkannya dimana mereka menyisihkan dana khusus untuk zakat, infaq, dan sedekah rutin untuk periode tertentu. Sebagian pelaku usaha menyalurkannya melalui panti asuhan dan sebagian lain menyalurkan secara personal atau melalui media penyaluran dana sosial lainnya.

Potret lapangan tersebut menunjukkan bahwa para pelaku usaha kecil online shop anggota HIPMI PT UINSA dapat dikategorikan telah memahami pengelolaan keuangan Islami. Dengan menetapkan anggaran khusus untuk untuk zakat, infaq dan sadaqah artinya tujuan maqāṣid alsharī'ah dari pengelolaam keuangan

\footnotetext{
${ }^{12}$ Naili Saadah, "Perencanaan Keuangan Islam Sederhana..., 123

${ }^{13}$ Wulan Ayodya, Endang Koswara, 101 Solusi Jadi Pengusaha yang Berkah (Jakarta: Elex Media Komputindo, 2014), 205.

${ }^{14}$ Ibid, 203.
} 
tersebut tercapai. ${ }^{15}$ Lebih lanjut peneliti juga akan memaparkan hasil analisa mengenai pengelolaan keuangan yang diterapkan oleh para pelaku usaha kecil online shop anggota HIPMI PT UIINSA dalam bisnisnya.

\section{OPERASIONAL USAHA}

\section{a. Sumber dana usaha}

Sumber dana atau modal untuk membiayai usaha dapat berasal dari berbagai sumber. Prinsip penting dalam pengelolaan keuangan secara Islami yakni sumber modal harus terhindar dari unsur maysir, gharar, riba dan dzalim. Dari 10 informan dalam penelitian ini, 3 informan menjalankan usaha dengan sumber modal dari pinjaman bank, sedangkan 7 lainnya menggunakan modal yang bersumber dari tabungan pribadi dan dana dari orang tua. Seperti yang sudah disebutkan sebalumnya bahwa sumber modal harus terhindar dari unsur maysir, gharar, riba dan dzalim. Fakta empiris yang ditemukan dalam penelitian ini semua pelaku usaha yang menggunakan modal dari bank masih menggunakan jasa bank konvensional dengan alasan kemudahan akses dan keringanan bunga yang diberikan. Hal ini tidak sejalan dengan prinsip pengelolaan keuangan dalam Islam dimana sumber modal yang

\footnotetext{
${ }^{15}$ Aini Masruroh, "Mengelola Keuangan Secara Syariah dalam Rangka Menumbuhkan Good Money Habit", al Iqtishad, Vol V, No. 1 (Januari 2013), 86.
}

digunakan mengandung unsur-unsur yang seharusnya dihindari.

Sumber dana sendiri nantinya akan menentukan bagaimana cara pelaku usaha menggunakan uang untuk kegiatan usaha dan derajat kepemilikan atas usaha tersebut. ${ }^{16}$ Melihat fakta dilapangan mayoritas pelaku usaha lebih memilih untuk menggunakan modal sendiri. Menjalankan usaha dengan modal sendiri dirasa relatif lebih memudahkan bagi pengusaha, baik dari segi memperolehnya maupun pengelolaannya meskipun terdapat kelemahan yakni keterbatasan jumlah modal.

\section{b. Penganggaran}

Penyusunan anggaran merupakan proses untuk membantu melaksanakan fungsi perencanaan dan pengendalian yang efektif. Rancangan anggaran dapat menghindarkan usaha dari pembengkakan pengeluaran yang dapat meningkatkan resiko kebangkrutan.

Berdasarkan hasil wawancara terdapat 2 informan yang membuat penganggaran secara detail dan terstruktur dalam menjalankan usahanya dimana 1 informan menyusun sendiri dan 1 informan lainnya didampingi oleh seorang mentor. Sedangkan mayoritas informan lain tidak membuat rancangan anggaran secara detail. Mereka hanya membuat rancangan sederhana dan tidak tertulis. Kemudian direalisasikan sesuai kebutuhan saat itu, tidak terdapat

\footnotetext{
${ }^{16}$ Andreas, Manajemen Keuanga..., 25.
} 
rencana yang terstruktur untuk jangka waktu tertentu.

Berdasarkan fakta dilapangan mayoritas pelaku usaha anggota HIPMI masih menganggap pembuatan rancangan anggaran bukan sesuatu yang penting bagi usaha mereka. Para pelaku usaha lebih memilih menggunakan cara tradisional ini dengan alasan lebih mudah, dan usaha mereka tetap berjalan dan berkembang dengan cara ini.

\section{c. Laporan Keuangan}

Hampir semua informan tidak memiliki laporan keuangan dalam menjalankan usahanya, hanya 1 informan yang memiliki laporan keuangan dengan memanfaatkan aplikasi keuangan digital. Para informan lain yang belum memiliki laporan keuangan dalam menjalankan usahanya hanya membuat pencatatan keuangan sederhana dalam menjalankan bisnisnya seperti mencatat biaya pembelian barang atau bahan baku, dan penjualan setiap unit produk. Tidak terdapat pencatatan lebih detail terkait biaya yang dikeluarkan seperti biaya bensin, biaya pulsa, biaya internet dan sebagainya sehingga sulit bagi pelaku usaha untuk mengetahui posisi keungan usaha mereka. Namun, pencatatan sederhana yang telah dilakukan para pelaku usaha ini merupakan hal positif dalam menjalankan bisnis. Minimal mereka memiliki data sederhana terkait selisih dari pemasukan dan pengeluaran dalam bisnis mereka. Selama keuntungan tidak mengurangi modal utama mereka menganggap bisnis dalam kondisi baik. Menurut informan pembuatan laporan keuangan justru akan menambah beban kerja mereka meskipun kini telah banyak aplikasi keuangan yang membantu pembuatan laporan keuangan.

Pembuatan laporan keuangan berfungsi untuk memberikan informasi tentang posisi keuangan, kinerja, dan arus kas sehingga memudahkan dalam membuat keputusan-keputusan dalam bisnis. Berdasarkan data empiris, rendahnya praktek pembuatan laporan keuangan ini disebabkan oleh kurangnya tenaga kerja dalam bisnis tersebut. Hal ini yang menyebakan para pelaku usaha memilih untuk fokus pada proses produksi, promosi dan distribusi.

\section{d. Manajemen Kas}

Manajemen kas adalah pengelolaan kas yang dimiliki oleh suatu entitas dengan memperhatikan upayaupaya pengendalian yang baik sehingga dapat digunakan secara efisien dan efektif dalam aktivitas operasional entitas tersebut. Berdasarkan hasil wawancara seluruh pelaku usaha memiliki kas baik berupa uang tunai maupun kas bank dalam sejumlah dan per periode tertentu untuk operasional usaha mereka. Akan tetapi tidak semua informan menerapkan manajemen kas pada usaha mereka. Mereka juga belum memiliki pencatatan pada setiap transaksi yang dilakukan namun keseluruhan uang usaha masih menjadi 
satu, sehingga kemungkinan adanya uang menganggur tinggi.

Bagi pelaku usaha yang menerapkan manajemen kas pada usahanya, kas yang ada diperuntukan untuk modal produksi kembali juga digunakan untuk keperluan uang kembalian, dan traksaksi kecil yang membutuhkan pembayaran cepat. Meski masih sederhana pencatatan kas masuk dan keluar juga telah dilakukan oleh para pelaku usaha ini. Dengan pencatatan ini pelaku usaha dapat mengontrol arus keuangan mereka, dan dapat segera melakukan tindakan ketika terjadi penurunan atau peningkatan pendapatan dan pengeluaran sehingga risiko kerugian dapat diminimalisir.

\section{e. Tabungan}

Tabungan merupakan salah satu produk perbankan yang lazim dipakai oleh masyarakat, khususnya untuk seorang pelaku bisnis. Beberapa pelaku usaha bisnis online menjadikan perbankan sebagai pendamping dalam bisnisnya. ${ }^{17}$ Berdasarkan fakta lapangan mayoritas informan mempunyai tabungan pribadi dan tabungan usaha. Kebanyakan dari mereka membedakan rekening pribadi dan rekening usaha dengan tujuan agar keuangan tida bercampur dan tidak mengurangi modal yang mereka miliki sehingga usaha mereka dapat berkelanjutan. Pemisahan tabungan yang di tetapkan oleh para

${ }^{17}$ Darsono, Ali Sakti, Ascarya, Perbankan Syariah di Indonesia, (Jakarta: PT RajaGrafindo Persada, 2017), 204. pelaku usaha didasarkan pada analisa usaha dan keuangan pribadi tentunya bersadarkan hasil usaha yang didapat oleh pelaku usaha.d Sehingga jelaslah terlihat bahwa engan pemisahan tabungan usaha dan tabungan pribadi berperan dalam memberikan kemaslahatan berjalannya usaha dalam jangka panjang.

\section{f. Investasi}

Dari 10 informan beberapa diantaranya mengalokasikan dana yang mereka miliki untuk investasi berguna sebagai back up ketika usaha mengalami penurunan dikemudian hari. Beberapa pelaku usaha berinvestasi pada instrumen investasi seperti deposito, properti dan emas. Selain itu terdapat pelaku usaha yang menginvestasikan dananya dibidang usaha lain.

Dalam investasi dikenal konsep high risk, high return, artinya semakin tinggi risiko dalam suatu instrumen maka semakin besar potensi imbal hasil yang akan diperoleh. Para pelaku usaha berinvestasi dengan tujuan agar dana yang mereka miliki dapat menghasilkan keuntungan yang lebih maksimal sekaligus untuk berjaga-jaga jika usaha mereka membutuhkan dana tambahan dikemudian hari, sehingga mereka memilih instrumen yang tergolong aman dan minim risiko.

\section{g. Asuransi}

Asuransi bisnis merupakan salah satu produk asuransi yang dikhususkan untuk melindungi bisnis. Asuransi ini memiliki berbagai manfaat seperti 
pengalihan risiko, pengumpulan dana dan premi yang seimbang dan juga dapat merangsang pertumbuhan bisnis, mencegah kerugian, pengendalian kerugian, memiliki manfaat sosial dan sebagai tabungan. Asuransi dalam bisnis juga dapat menjadi investasi dana dan invisible earnings. ${ }^{18}$ Dari 10 informan, secara keseluruhan pelaku usaha kecil tidak menggunakan produk asuransi.

Ada begitu banyak hal yang tidak bisa diprediksi. Untuk mencegah adanya kerugian besar saat hal-hal yang tidak diinginkan terjadi pada usaha, memberikan jasa asuransi adalah solusi yang tepat baik secara mental maupun finansial. Sayangnya, saat ini masih minim kesadaran dari pelaku usaha untuk membeli produk asuransi bagi bisnis dan usahanya.

\section{h. Pajak dan Zakat}

Pembayaran pajak merupakan kewajiban seorang warga Negara. Pajak sebagai sumber keuangan negara, Kementerian Keuangan telah mengesahkan Rancangan Peraturan Menteri Keuangan tentang Tata Cara Perpajakan Pelaku Usaha Perdagangan Berbasis Elektronik (RPMK Pajak Ecommerce). Dalam RPMK Pajak $E$ commerce terdapat dua jenis pajak yang diatur bagi pengusaha $e$-commerce yakni Pajak Pertambahan Nilai (PPN) dan

\footnotetext{
${ }^{18}$ Mustica Bintang, Jaenal Effendi, Tanti Novianti, Islamic Insurance Efficiency in Indonesia using Data Envelopment Analysis Approach, Jurnal Al-Muzara'ah, Vol.5, No.1, (2017).
}

Pajak Penghasilan (PPh). ${ }^{19}$ Disisi lain setiap orang yang telah memenuhi syarat dan rukun zakat maka dia harus mengeluarkan zakatnya. Ada zakat harta, zakat perdagangan, zakat penghasilan, zakat hewan ternak, dan zakat barang tambang. Zakat adalah ibadah maliyah ijtimaiyyah, artinya ibadah harta sosial.

Untuk seluruh informan memberikan keterangan bahwa mengenai pajak bisnis online masih belum terealisasikan dan belum adanya pemahaman dan pengarahan selanjutnya. Disisi lain dari 10 informan beberapa diantaranya sudah menganggarkan setiap tahunnya untuk pembayaran zakat usaha mereka dan zakat pribadi. Selain itu beberapa informan belum mengeluarkan zakat secara rutin dikarenakan ketidaktahuan tentang zakat usaha dan perhitungannya.

Analisis Pengelolaan Keuangan Islam Pada Pelaku Usaha Kecil Bisnis Online Anggota Himpunan Pengusaha Muda Indonesia Perguruan Tinggi Universitas Islam Negeri Sunan Ampel Surabaya (HIPMI PT UINSA)

Pemahaman pelaku usaha kecil anggota HIPMI PT UINSA terhadap pengelolaan keuangan Islam dapat dikategorikan dalam kategori baik.

\footnotetext{
${ }^{19}$ Media Keuangan, Kesetaraan Pajak Untuk ECommerce, Jurnal Transparansi Informasi Kebijakan Fiskal, Vol. XIII/No. 126/Maret (2018).
} 
Kategori ini memiliki arti bahwa para pelaku usaha telah memiliki pengetahuaan dan keyakinan bahwa dalam pengelolaan keuangan secara Islami mengutamakan untuk menghindari adanya penghasilan yang tidak halal, seperti adanya riba, maysir, gharar dan juga mengutamakan untuk menyisihkan sebagian rezekinya untuk dibelanjakan di jalan Allah seperti mengeluarkan zakat, infaq, dan sedekah. 20

Namun meski memiliki pemahaman terhadap pengelolaan keuangan Islam yang baik, fakta dilapangan menunjukkan bahwa keterampilan pengelolaan keuangan usaha anggota HIPMI PT UINSA tergolong kurang baik. Meskipun telah melakukan pemisahan antara keuangan usaha dan keuangan pribadi dan memiliki manajemen kas, namun pelaku usaha masih menerapkan pencatatan keuangan sederhana dalam menjalankan usahanya tanpa disertai penyimpanan dokumen pendukung. Pengetahuan mengenai pengelolaan keuangan yang dimiliki tidak menjadikan pelaku usaha anggota HIPMI PT UINSA menerapkan pembuatan laporan keuangan secara terstruktur yang terdiri atas, laporan arus kas, neraca, laporan perubahan modal, dan laporan laba rugi. Diperlukan adanya pendekatan manajerial diharapkan dapat menambah

${ }^{20}$ Wulan Ayodya, Endang Koswara, 101 Solusi Jadi Pengusaha yang Berkah (Jakarta: Elex Media Komputindo, 2014), 205. wawasan serta teknik dalam pengelolaan usahan terutama yang berkaitan dengan keuangan. Pendekatan dapat berupa sosialisasi maupun pelatihan guna mendorong kesadaran pelaku usaha terhadap pentingnya penyusunan laporan keuangan.

Selain itu pembuatan anggaran juga dalam kategori kurang baik. Meski telah mengetahui resiko penurunan atau kebangkrutan dapat terjadi sewaktuwaktu namun penganggaran yang dilakukan hanya sebatas menggunakan insting dan perkiraan tanpa terdapat perencanaan yang terstruktur. Fakta ini menunjukkan bahwa pemahaman mengenai pengelolaan keuangan yang baik tidak benar-benar membuat pelaku usaha menerapkan pengetahuan tersebut dalam bisnis mereka.

Terkait dengan investasi dan tabungan para pelaku usaha anggota HIPMI PT UINSA dapat dikategorikan memiliki pengelolaan yang cukup baik. Berdasarkan fakta lapangan beberapa pelaku usaha telah melakukan investasi, meski masih terbatas pada instrumen investasi berupa emas, deposito, properti, pada usaha lain, maupun pengembangan usaha mereka sendiri. Fakta tersebut menunjukkan kecenderungan dari seluruh informan dalam penelitian ini memilih untuk berinvestasi pada bidang atau instrumen yang memiliki risiko rendah. Para pelaku usaha berinvestasi dengan tujuan agar dana yang mereka miliki dapat menghasilkan keuntungan yang lebih 
maksimal sekaligus untuk berjaga-jaga jika usaha mereka membutuhkan dana tambahan dikemudian hari, sehingga mereka memilih instrumen yang tergolong aman dan minim risiko.

Di sisi lain dalam hal asuransi, belum terdapat pelaku usaha anggota HIPMI PT UINSA yang memiliki asuransi untuk usahanya. Usaha kecil dan menengah bisa jadi lebih rentan terhadap fluktuasi kondisi ekonomi dan ganguan bisnis lainnya jika terjadi musibah. Namun pelaku usaha sekarang masih kurang menyadari akan banyaknya risiko yang mungkin timbul pada setiap pendirian usaha. Sehingga asuransi bisnis pada setiap usaha kurang diminati. Hal ini dikarenakan asuransi dianggap bukan sebagai kebutuhan yang utama tapi sebagai kebutuhan pelengkap.

Terkait pajak, zakat infaq, dan sedekah para pelaku usaha anggota HIPMI PT UINSA memiliki pemahaman dan keterampilan yang baik terkait kewajiban dari sisi agamanya, namun kurang patuh terhadap kewajiban warga negara. Pembayaran zakat merupakan kewajiban agama seorang muslim sebagai pembersih harta bagian dari rukun Islam. Para pelaku usaha telah memiliki rutinitas pembayaran zakat, begitu juga dengan kegiatan rutinitas infaq dan sedekah akan hasil usaha yang diperoleh. Terkait pajak belum ada pelaku usaha yang membayarkan kewajiban pajaknya. Faktor utama yang mendorong hal ini adalah kurangnya pengetahuan pelaku usaha tentang sistem perhitungan dan pembayaran pajak bisnis online yang kini mulai diterapkan. Berdasarkan fakta ini pemerintah perlu untuk melakukan sosialisasi lebih masif guna menigkatkan literasi pelaku usaha terkait kebijakan wajib pajak.

\section{PENUTUP}

Pada dasarnya dalam mengelola keuangan secara Islami tidak berbeda dengan pengelolaan keuangan konvensional. Pengelolaan keuangan secara Islami lebih mengutamakan untuk menghindari adanya penghasilan yang tidak halal, seperti adanya riba, maysir, gharar dan juga mengutamakan untuk menyisihkan sebagian rezekinya untuk dibelanjakan di jalan Allah seperti mengeluarkan zakat, infaq, dan sedekah. Dari penelitian ini peneliti menyimpulkan beberapa hal berikut:

1. Untuk sumber modal awal hampir semua pelaku usaha menggunakan modal pribadi. Mereka menghindari sumber modal berupa pinjaman dari bank atau pihak luar untuk menghindari risiko dari pinjaman tersebut. Namun ada beberapa informan yang menggunakan modal pinjaman dari bank.

2. Untuk pengelolaan yang berkaitan dengan pengelolaan keuangan secara umum mayoritas pelaku usaha masih belum menjalankannya. Mayoritas pelaku usaha masih belum membuat 
Novi Febriyanti, Kiky Dzakiyah

penganggaran, laporan keuangan dan manajemen kas. Dalam menjalankan usaha ini, pelaku usaha masih menggunakan pengendalian usaha berdasarkan insting dengan alasan lebih mudah, dan usaha mereka tetap berjalan dan berkembang dengan cara ini.

3. Untuk tabungan hampir semua informan mempunyai tabungan pribadi dan tabungan usaha. Kebanyakan dari mereka membedakan rekening pribadi dan rekening usaha walaupun ada beberapa yang masih tercampur.

4. Dalam hal investasi beberapa pelaku usaha yang telah melakukan investasi dalam bentuk emas, deposito, properti, pada usaha lain, maupun pengembangan usaha mereka sendiri.

5. Dari 10 informan, secara keseluruhan pelaku usaha kecil tidak menggunakan produk asuransi untuk perlindungan aset mereka.

6. Untuk pajak secara keseluruhan para pelaku usaha belum membayarkannya dikarenakan ketidaktahuan terhadap peraturan dari kebijakan tersebut. Sedangkan untuk zakat, infaq, dan sadaqah hampir seluruh informan telah memiliki anggaran khusus untuk pembayarannya.

\section{DAFTAR PUSTAKA}

Afrizal. Metode Penelitian Kualitatif. Jakarta: PT RajaGrafindo Persada. 2016.

Agus Purnomo, Atika Zahra Maulida, "Implementasi Islamic Financial Planning dalam Perencanaan Keuangan Pengusaha Muslim Alumni Gontor", Nuansa Vol. 14 N0. 1 (I Januari - Juni 2017).

Andreas. Manajemen Keuangan UKM. Yogyakarta: Graha Ilmu, 2011.

Ascarya, Darsono, Ali Sakti. Perbankan Syariah di Indonesia. Jakarta: PT RajaGrafindo Persada. 2017

Ayodya, Wulan, Endang Koswara. 101 Solusi Jadi Pengusaha yang Berkah. Jakarta: Elex Media Komputindo, 2014.

Corporation Federal Deposit Insurance. "Fueling Your Business: A Guide to Financing Your Small Business", dalam www.fdic.gov diakses pada 20 Maret 2019.

Danim, Sudarwan Menjadi Peneliti Kualitatif. Bandung: Pustaka Setia. 2002.

Karniawati, Yuni. "Pemahaman dan penerapan Pencatatan Keuangan Pada Usaha Mikro dan Kecil (UMK) dalam Usaha Furniture Mebel", (Skripsi-Universitas Airlangga, 2018).

Masruroh Aini. "Mengelola Keuangan Secara Syariah dalam Rangka Menumbuhkan Good Money Habit”, 
al Iqtishad, Vol V, No. 1 (Januari 2013).

Media Keuangan, Kesetaraan Pajak Untuk E-Commerce, Jurnal

Transparansi Informasi Kebijakan

Fiskal, Vol. XIII/No. 126/Maret (2018).

Miftah, Shabur et al. "Implementasi E-

Commerce Sebagai Media Penjualan

Online (Studi Kasus Pada Toko

Pstbrik Kota Malang), Jurnal Administrasi Bisnis Vol 29 No 1

(Desember 2015).

Mustica Bintang, Jaenal Effendi, Tanti

Novianti, Islamic Insurance Efficiency in Indonesia using Data Envelopment Analysis Approach,
Jurnal Al-Muzara'ah, Vol.5, No.1, (2017).

Purkon, Arip. Bisnis Online Syariah. Jakarta: Gramedia Pustaka Utama. 2014.

Saadah, Naili, "Perencanaan Keuangan Islam Sederhana dalam Bisnis ECommerce pada Pengguna Online Shop", Economica: Jurnal Ekonomi Islam, Vol. 9 No. 1 (2018).

Saferi, Intan, Sri Retno Handayani, "Identifikasi Pengelolaan Keuangan terhadap Peluang Usaha Online", Journal and Proceeding Fakultas Ekonomi dan Bisnis Unsoed Vol. 4 No. 1 (2014).

Syarifuddin, Amir. Garis-Garis Besar Fiqh. Jakarta: Prenada Media, 2003. 